\title{
Respon Pertumbuhan dan Produksi Tanaman Semangka (Citrullus vulgaris Schard) Akibat Pemberian Abu Sabut Kelapa dan Pupuk Pupuk NPK Phonska
}

\author{
Nursayuti ${ }^{1}$ \\ Dosen Fakultas Pertanian Program studi Agroteknologi Universitas Almuslim Matang \\ glumpang Dua Bireuen \\ Email: nursayuti1979@gmail.com
}

\begin{abstract}
ABSTRAK
Penelitian ini bertujuan untuk mengetahui respon tanaman semangka terhadap pemberian berbagai dosis abu sabut kelapa dan pupuk NPK phonska. Penelitian dilaksanakan di Gampong Geudong-Geudong Kecamatan Kota Juang Kabupaten Bireuen dengan ketinggian tempat 5 mdpl pada bulan Agustus sampai dengan bulan Oktober 2020. Rancangan percobaan yang dilakukan dalam penelitian ini adalah Rancangan Acak Kelompok (RAK) faktorial dengan dua faktor perlakuan. Faktor I : Dosis Abu Sabut Kelapa (A) terdiri dari 4 taraf perlakuan yaitu : $\mathrm{A}_{0}=$ Tanpa aplikasi Abu Sabut Kelapa, $A_{1}=4$ ton/ha $(2500 \mathrm{~g} / \mathrm{plot}), \mathrm{A}_{2}=8$ ton/ha $(5000 \mathrm{~g} / \mathrm{plot})$ dan $\mathrm{A}_{3}=12$ ton $/ \mathrm{ha}(5000$ $\mathrm{g} /$ plot). Faktor II : pupuk NPK phonska (N) terdiri dari 3 taraf perlakuan yaitu : $\mathrm{N}_{0}=$ Tanpa pupuk NPK phonska (kontrol), $\mathrm{N}_{1}=400 \mathrm{~kg} / \mathrm{ha}(250 \mathrm{~g} / \mathrm{plot})$ dan $\left.\mathrm{N}_{2}=800 \mathrm{~kg} / \mathrm{ha} 500 \mathrm{~g} / \mathrm{plot}\right)$. Pengamatan yang diamati dalam penelitian ini meliputi panjang tanaman umur 20 dan $40 \mathrm{HST}$, jumlah buah per tanaman, berat buah per tanaman, , dan berat buah per plot. Hasil Penelitian menunjukkan bahwa pemberian abu sabut kelapa berpengaruh sangat nyata terhadap berat buah semangka per plot, akan tetapi berpengaruh tidak nyata terhadap pertumbuhan tinggi tanaman, jumlah buah, berat buah per tanaman,. Perlakuan terbaik dijumpai pada perlakuan abu sabut kelapa dosis $2500 \mathrm{~g} / \mathrm{plot}\left(\mathrm{A}_{1}\right)$. Pemberian pupuk NPK berpengaruh sangat nyata terhadap berat buah semangka per plot, akan tetapi berpengaruh tidak nyata terhadap pertumbuhan tinggi tanaman, jumlah buah, berat buah per tanaman, diameter buah dan berat berangkasan kering tanaman semangka. Perlakuan terbaik dijumpai pada perlakuan pupuk NPK dosis $250 \mathrm{~g} /$ plot $\left(\mathrm{N}_{1}\right)$. Tidak terdapat interaksi yang nyata antara kombinasi perlakuan abu sabut kelapa dan pupuk NPK terhadap semua peubah yang diamati
\end{abstract}

Kata Kunci : Abu Sabut Kelapa, Pupuk NPK, Semangka

\section{PENDAHULUAN}

Tanaman semangka merupakan tanaman musim panas yang membutuhkan iklim kering dan panas untuk pertumbuhannya. Semangka banyak digemari oleh berbagai lapisan masyarakat karena rasanya yang manis, aromanya yang khas dan mengandung banyak air, Selain itu juga merupakan sumber vitamin A, dan C. Beberapa faktor yang mempengaruhi hasil produksi semangka yaitu produktivitas tanah yang rendah akibat pengguanan pupuk anorganik yang berlebihan, sehingga menyebabkan tingkat kesuburan tanah menurun dan persediaan bahan organik berkurang. Berbagai usaha dilakukan petani untuk meningkatkan ketersediaan unsur hara dalam tanah untuk mencapai produksi yang optimal, salah satunya melalui pemupukan terpadu antara pupuk anorganik dan organik.

Salah satu alternatif untuk meningkatkan produktivitas tanah adalah dengan pemberian bahan organik. Bahan organik yang mempunyai potensi untuk digunakan dan mudah didapat antara lain adalah sabut kelapa. Sabut kelapa merupakan limbah pertanian yang selama ini kurang dimanfaatkan keberadaannya (Trisnaningsih dkk., 2014). Pemanfaatan sabut kelapa sebagai pengganti pupuk KCl merupakan salah satu alternatif untuk menurunkan biaya produksi. Pemberian sabut kelapa dalam bentuk abu memberikan keuntungan bila dibandingkan pemberian dalam bentuk segar, karena 
pemberian dalam bentuk abu memungkinkan unsur hara yang terkandung di dalamnya untuk lebih cepat tersedia bagi tanaman.

Menurut Prajnanta (2011), tanaman semangka dalam pertumbuhannya membutuhkan lebih banyak kalium dibandingkan nirogen dan fosfor. Kalium yang diberikan ke dalam tanah diserap tanaman dalam bentuk ion yang berperan dalam mengatur tekanan osmotik sel. Foth (2014) menyatakan bahwa kalium di dalam tanaman berfungsi meningkatkan sintesis dan translokasi karbohidrat sehingga meningkatkan ketebalan dinding sel dan kekuatan batang. Pemberian bahan organik saja dalam jangka pendek belum mampu memenuhi kebutuhan hara bagi tanaman semangka, sehingga perlu dilakukan penambahan pupuk anorganik seperti pupuk NPK. Pupuk NPK merupakan pupuk campuran yang umumnya mengandung lebih dari satu macam unsur hara tanaman. Pupuk NPK mengandung unsur hara makro yang secara umum dibutuhkan oleh tanaman dan dapat memberikan keseimbangan hara yang baik untuk pertumbuhan dan produksi tanaman. Kelebihan pupuk NPK yaitu dengan satu kali pemberian pupuk dapat mencakup beberapa unsur hara sehingga lebih efisien dalam penggunaan bila dibandingkan dengan pupuk (Hutasoit, dkk., 2018).

Kelebihan pupuk NPK yaitu dengan satu kali pemberian pupuk dapat mencakup beberapa unsur hara sehingga lebih efisien dalam penggunaan bila dibandingkan dengan pupuk tunggal. Hasil Penelitian Purba, dkk (2015), menunjukkan dosis pupuk NPK terbaik adalah perlakuan 120 gram/tanaman yang dapat menghasilkan berat rataan buah semangka $2,97 \mathrm{~kg}$, mutu buah kelas A $76,67 \%$ produksi per tanaman $5,70 \mathrm{~kg}$, produksi per plot 28,51 kg dan produksi per hektar 25,34 ton. Penggunaan pupuk abu sabut kelapa dan pupuk NPK dapat meningkatkan kandungan unsur hara yang dibutuhkan di dalam tanah serta dapat dimanfaatkan langsung oleh tanaman. Hal ini sejalan dengan pendapat Sutedjo (2012) bahwa pemberian pupuk organik kombinasi pupuk anorganik kedalam tanah dapat menambah ketersediaan hara yang cepat bagi tanaman.

\section{BAHAN DAN METODE PENELITIAN}

Penelitian telah dilaksanakan di Gampong Geudong-Geudong Kecamatan Kota Juang Kabupaten Bireuen dengan ketinggian tempat 5 mdpl pada bulan Agustus sampai dengan bulan Oktober 2020. Bahan yang digunakan dalam penelitian ini yaitu : benih semangka Hibrida varietas Red New Dragon, pupuk NPK Phonska, sabut kelapa, minyak tanah, koran dan air. Alat yang digunakan dalam penelitian ini yaitu cangkul, korek, garu, ember, gembor, sprayer, timbangan, gunting, cutter, drum, camera, papan sampel, meteran dan alat tulis.

Metode yang digunakan dalam penelitian ini adalah dengan menggunakan rancangan acak kelompok (RAK) faktorial yang terdiri dari 2 faktor yang diteliti yaitu dosis abu sabut kelapa (A) dan pupuk NPK phonska (N). Faktor I yaitu : Dosis Abu Sabut Kelapa (A) terdiri dari 4 taraf : $\mathrm{A}_{0}=$ Tanpa aplikasi Abu Sabut Kelapa, $\mathrm{A}_{1}=2500 \mathrm{~g} / \mathrm{plot}(4 \mathrm{ton} / \mathrm{ha}), \mathrm{A}_{2}=5000 \mathrm{~g} / \mathrm{plot}(8 \mathrm{ton} / \mathrm{ha}), \mathrm{A}_{3}=7500 \mathrm{~g} / \mathrm{plot}$ (12 ton/ha).sedangkan faktor II : pupuk NPK phonska (N) terdiri dari 3 taraf : $\mathrm{N}_{0}=$ Tanpa pupuk NPK phoska (kontrol), $\mathrm{N}_{1}=250 \mathrm{~g} /$ plot $(400 \mathrm{~kg} / \mathrm{ha}), \mathrm{N}_{2}=500 \mathrm{~g} / \mathrm{plot}(800 \mathrm{~kg} / \mathrm{ha})$. Plot percobaan berukuran $2,5 \mathrm{~m}$ x 2,5 m sebanyak 36 petak. Jarak antar ulangan $50 \mathrm{~cm}$ dan jarak antar perlakuan $50 \mathrm{~cm}$. Aplikasi pupuk NPK dilakukan sebanyak 1 kali yaitu 1 hari sebelum pemasangan mulsa, yang diberikan dengan dosis sesuai perlakuan masing-masing perplot perlakuan. Aplikasi dilakukan dengan cara menyebarkan pupuk NPK disetiap plot percobaan. Aplikasi abu sabut kelapa diaplikasi pada saat tanaman semangka berumur 15 HST, 30 HST dan 45 HST, dengan cara membuat lubang lingkaran di sekitar tanaman semangka. Dosis abu sabut kelapa yang diberikan pada plot percobaan sesuai dengan perlakuan yaitu : $250 \mathrm{~g} /$ pertanaman, $500 \mathrm{~g} /$ pertanaman, dan $750 \mathrm{~g} /$ pertanaman. 


\section{HASIL DAN PEMBAHASAN}

\section{Pengaruh Abu Sabut Kelapa}

\section{Panjang Tanaman (cm)}

Nilai rata-rata panjang tanaman semangka umur 20 dan 40 HST akibat perlakuan abu sabut kelapa setelah diuji $\mathrm{BNT}_{0,05}$ di sajikan pada Tabel 1.

Tabel 1. Rata-rata Panjang Tanaman Semangka umur 20 dan 40 HST Akibat Pengaruh Pemberian Abu Sabut Kelapa

\begin{tabular}{ccc}
\hline \multirow{2}{*}{ Perlakuan Abu Sabut Kelapa } & \multicolumn{2}{c}{ Panjang Tanaman (cm) } \\
\cline { 2 - 3 } & $20 \mathrm{HST}$ & $40 \mathrm{HST}$ \\
\hline $\mathrm{A}_{0}=$ Kontrol & 30.20 & 40.54 \\
$\mathrm{~A}_{1}=2500 \mathrm{~g} /$ plot $(4$ ton/ha) & 30.26 & 40.63 \\
$\mathrm{~A}_{2}=5000 \mathrm{~g} /$ plot (8 ton/ha) & 30.21 & 40.71 \\
$\mathrm{~A}_{3}=7500 \mathrm{~g} /$ plot (12 ton/ha) & 30.09 & 40.80 \\
\hline $\mathrm{BNT}_{0,05}$ & - & -
\end{tabular}

Keterangan : Angka yang diikuti oleh huruf yang sama pada kolom yang sama berbeda tidak nyata pada Uji BNT 0.05

Tabel 1 memperlihatkan bahwa pemberian abu sabut tidak berpengaruh nyata terhadap panjang tanaman semangka pada umur 20 dan 40 HST. Hal ini menunjukkan bahwa pemberian abu sabut kelapa tidak dapat mempengaruhi pertumbuhan tanaman semangka. Hal ini disebabkan oleh pemberian abu sabut kelapa yang tidak dapat memicu langsung terhadap pertumbuhan vegetatif tanaman semangka, karena dosis tidak berada dalam keadaan optimum untuk memicu pertumbuhan tanaman semangka, sehingga belum memperlihatkan pengaruh langsung pada pertumbuhan tinggi tanaman semangka. Hal ini sesuai dengan pendapat Wibawa (2008) bahwa pertumbuhan tanaman yang baik dapat tercapai apabila unsur hara yang dibutuhkan untuk pertumbuhan dan perkembangan tanaman berada dalam bentuk tersedia, seimbang dan dalam dosis yang optimum.

Pertumbuhan awal tanaman akan membutuhkan jumlah unsur hara yang banyak, dengan tersedianya unsur hara dalam jumlah yang cukup dan seimbang untuk proses pertumbuhan tanaman, apabila unsur hara tersebut tidak cukup untuk dimanfaatkan oleh tanaman maka, proses pembelahan sel, proses fotosintesis, dan proses pemanjangan sel tidak akan berlangsung dengan cepat dan dapat mengakibatkan beberapa organ tanaman terhambat terutama pada fase vegetatif (Arinong dkk., 2015).

\section{Jumlah Buah Per Tanaman (Buah)}

Nilai rata-rata jumlah buah per tanaman semangka akibat perlakuan abu sabut kelapa setelah diuji $\mathrm{BNT}_{0,05}$ di sajikan pada Tabel 2.

Tabel 2. Rata-rata Jumlah Buah Per Tanaman Semangka Akibat Pengaruh Pemberian Abu Sabut Kelapa

\begin{tabular}{cc}
\hline Perlakuan Abu Sabut Kelapa & Jumlah Buah Per Tanaman (Buah) \\
\hline $\mathrm{A}_{0}=$ Kontrol & 1.60 \\
$\mathrm{~A}_{1}=2500 \mathrm{~g} /$ plot $(4$ ton $/ \mathrm{ha})$ & 1.72 \\
$\mathrm{~A}_{2}=5000 \mathrm{~g} /$ plot $(8$ ton $/ \mathrm{ha})$ & 1.58 \\
$\mathrm{~A}_{3}=7500 \mathrm{~g} /$ plot $(12$ ton $/ \mathrm{ha})$ & 1.65 \\
\hline $\mathrm{BNT}_{0,05}$ & - \\
\hline
\end{tabular}

Tabel 2 memperlihatkan bahwa pemberian abu sabut kelapa menunjukkan pengaruh tidak nyata terhadap jumlah buah per tanaman semangka, meskipun semua perlakuan tidak berpengaruh nyata, akan tetapi hasil jumlah buah per tanaman semangka terbaik dijumpai pada perlakuan dosis abu sabut $2500 \mathrm{~g} /$ plot $\left(\mathrm{A}_{1}\right)$. Hal ini menunjukkan bahwa pemberian abu sabut kelapa tidak dapat 
mempengaruhi pertumbuhan jumlah buah per tanaman semangka. Hal ini disebabkan oleh unsur hara yang diberikan melalui abu sabut kelapa belum mampu disuplai oleh akar ke bagian tajuk tanaman, sehingga belum mampu mengaktifkan pembuatan ATP dan fotosintesis yang berfungsi sebagai media transportasi, dengan adanya keadaan tersebut sehingga mengakibatkan berkurangnya khloropil pada daun dan dapat menyebabkan proses fotosintesis tidak sempurna yang mengakibatkan terhambatnya pertumbuhan atau pembentukan bunga sempurna pada tanaman semangka.

Amilda dan Putri (2019) menyatakan bahwa apabila pertumbuhan tanaman terhambat maka kelancaran translokasi unsur hara dan fotosintat ke bagian buah juga akan terhambat. Selain disebabkan oleh kurang optimalnya unsur hara yang diserap oleh tanaman semangka, juga disebabkan oleh kondisi lingkungan kurang mendukung yaitu pada saat pembungaan sering hujan sehingga menyebabkan banyak bunga yang rontok, sehingga menyebabkan jumlah buah yang dihasilkan dalam jumlah sedikit. Prawitasari (2013), menjelaskan bahwa perubahan pertumbuhan kearah perkembangan produksi tanaman dipengaruhi oleh kemampuan kerja enzim dalam tubuh tanaman dan faktor lingkungan.

\section{Berat Buah Per Tanaman (kg)}

Nilai rata-rata berat buah per tanaman semangka akibat perlakuan abu sabut kelapa setelah diuji $\mathrm{BNT}_{0,05}$ di sajikan pada Tabel 3.

Tabel 3. Rata-rata Berat Buah Per Tanaman Semangka Akibat Pengaruh Pemberian Abu Sabut Kelapa

\begin{tabular}{cc}
\hline Perlakuan Abu Sabut Kelapa & Berat Buah Per Tanaman $(\mathrm{kg})$ \\
\hline $\mathrm{A}_{0}=$ Kontrol & 2.25 \\
$\mathrm{~A}_{1}=2500 \mathrm{~g} /$ plot $(4$ ton $/ \mathrm{ha})$ & 2.33 \\
$\mathrm{~A}_{2}=5000 \mathrm{~g} /$ plot $(8$ ton $/ \mathrm{ha})$ & 2.15 \\
$\mathrm{~A}_{3}=7500 \mathrm{~g} / \mathrm{plot}(12$ ton $/ \mathrm{ha})$ & 2.28 \\
\hline $\mathrm{BNT}_{0,05}$ & - \\
\hline
\end{tabular}

Tabel 3 memperlihatkan bahwa pemberian abu sabut kelapa menunjukkan pengaruh tidak nyata terhadap berat buah per tanaman semangka. Hal ini menunjukkan bahwa pemberian abu sabut kelapa tidak dapat mempengaruhi pertumbuhan berat buah per tanaman semangka, walaupun berdasarkan hasil perhitungan analisis sidik ragam tidak berpengaruh nyata, akan tetapi hasil berat buah per tanaman semangka terbaik dijumpai pada perlakuan dosis abu sabut $2500 \mathrm{~g} / \mathrm{plot}\left(\mathrm{A}_{1}\right)$. Hal ini disebabkan oleh pemberian abu sabut kelapa yang dapat memberikan respon positif terhadap berat buah tanaman semangka, karena abu sabut kelapa dapat meningkatkan unsur hara kalium dan penyerapan air yang berperan dalam pembesaran buah semangka. Tiur (2015) menyatakan bahwa pemberian abu sabut kelapa memperlihatkan pengaruh sangat penting bagi tanaman semangka, karena dapat menyumbangkan hara, terutama unsur K sehingga K-tersedia di dalam tanah meningkat, dengan besarnya ketersediaan $\mathrm{K}$ di dalam tanah memungkinkan akar tanaman menyerap unsur $\mathrm{K}$ yang tersedia untuk memenuhi kebutuhannya.

Lingga dan Marsono (2011) menyatakan bahwa unsur hara kalium berfungsi sebagai katalisator untuk pembentukan karbohidrat dalam proses fotosintesis, pembentukan protein, translokasi gula dan protein, membantu dalam proses membuka dan menutupnya stomata, meningkatkan efisiensi penggunaan air, memperluas pertumbuhan akar, memperkuat jaringan dan organ-organ tanaman sehingga tidak mudah rontok, meningkatkan daya tahan tanaman terhadap serangan hama, serta meningkatkan kualitas dan kuantitas buah. 


\section{Berat Buah Per Plot (kg)}

Nilai rata-rata berat buah per plot tanaman semangka akibat perlakuan abu sabut kelapa setelah diuji BNT ${ }_{0,05}$ di sajikan pada Tabel 4.

Tabel 4. Rata-rata Berat Buah Per Plot Tanaman Semangka Akibat Pengaruh Pemberian Abu Sabut Kelapa

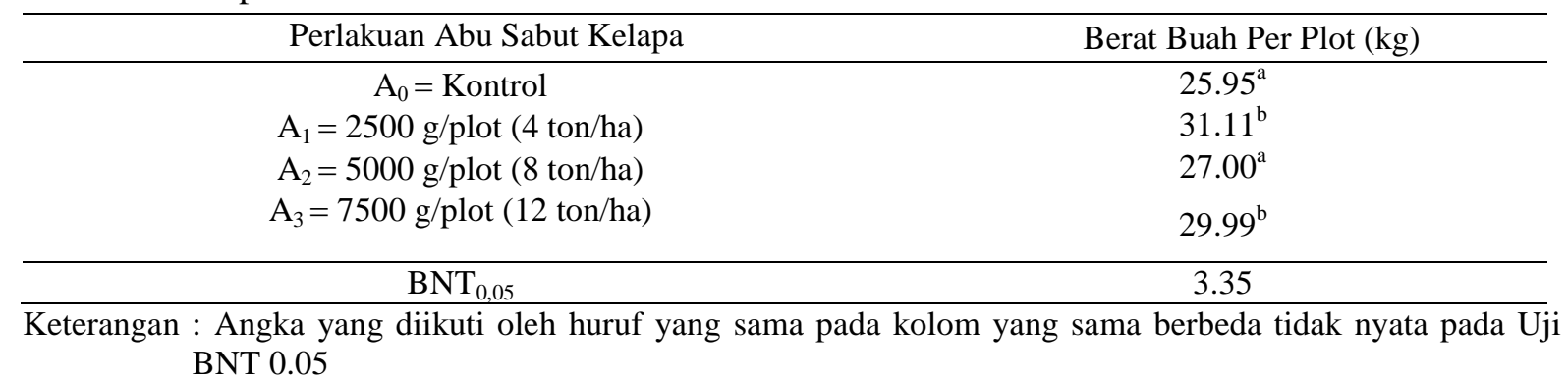

Tabel 4 memperlihatkan bahwa berat buah per plot tanaman semangka tertinggi dijumpai pada perlakuan pemberian abu sabut kelapa $2500 \mathrm{~g} / \mathrm{plot}\left(\mathrm{A}_{1}\right)$, sedangkan berat buah per plot tanaman semangka terendah dijumpai pada perlakuan tanpa pemberian abu sabut kelapa $\left(\mathrm{A}_{0}\right)$. Hal ini disebabkan oleh pemberian abu sabut kelapa dapat berperan sebagai katalisator dalam pembentukan tepung, gula dan lemak serta dapat meningkatkan kualitas hasil yang berupa terbentuknya bunga dan buah pada tanaman semangka. Hasil penelitian Daud dkk. (2017) menunjukkan bahwa abu sabut kelapa berpengaruh pada berat buah dan lingkar buah. Pemberian abu sabut kelapa 4 ton/ha (2500 $\mathrm{g} /$ plot) memberikan pengaruh terbaik pada berat buah dan lingkar buah.

Haryadi dkk. (2015), penambahan abu sabut kelapa memperlihatkan pengaruh yang sangat penting bagi tanaman, karena menyumbangkan hara, terutama unsur $\mathrm{K}$ tersedia di dalam tanah akan meningkat, dengan besarnya ketersediaan $\mathrm{K}$ di dalam tanah memungkinkan akar tanaman menyerap unsur $\mathrm{K}$ yang tersedia untuk memenuhi kebutuhannya. Kalium yang tepat juga akan mempengaruhi penampakan fisik buah yang besar, karena cadangan makanan yang ditimbun semakin banyak, selain itu unsur kalium juga dapat membantu meningkatkan serapan unsur lainnya khususnya $\mathrm{N}$ dan $\mathrm{P}$.

Menurut Prajnanta (2011), tanaman semangka dalam pembudidayaanya membutuhkan kalium lebih banyak dibandingkan nitrogen dan fosfor. Kalium yang diberikan ke dalam tanah diserap tanaman dalam bentuk ion yang berperan dalam mengatur tekanan osmotik sel, mengatur pendistribusian cairan ke dalam kompartemen bahan air, menjaga $\mathrm{pH}$ tubuh dan juga akan terlibat dalam setiap reaksi oksidasi dan reduksi serta ikut berperan dalam setiap metabolisme.

\section{Pengaruh Pupuk NPK Phonska}

\section{Panjang Tanaman (cm)}

Nilai rata-rata panjang tanaman semangka umur 20 dan 40 HST akibat pupuk NPK Phonska setelah diuji $\mathrm{BNT}_{0,05}$ di sajikan pada Tabel 7.

Tabel 7 memperlihatkan bahwa pemberian pupuk NPK menunjukkan pengaruh tidak nyata terhadap panjang tanaman semangka umur 20 dan 40 HST. Meskipun semua perlakuan pupuk NPK tidak berpengaruh nyata, akan tetapi hasil tinggi tanaman semangka terbaik dijumpai pada perlakuan kontrol $\left(\mathrm{N}_{0}\right)$. Hal ini menunjukkan bahwa pemberian pupuk NPK tidak dapat mempengaruhi pertumbuhan tanaman semangka, karena lahan yang digunakan dalam penelitian ini bekas pergiliran tanaman sehingga unsur hara dan bahan organik tersedia di tanah, walaupun pemberian pupuk NPK tidak memperlihatkan peningkatan parameter panjang tanaman semangka. 
Tabel 7. Rata-rata Panjang Tanaman Semangka umur 20 dan 40 HST Akibat Pengaruh Pupuk NPK Phonska

\begin{tabular}{ccc}
\hline \multirow{2}{*}{ Perlakuan Pupuk NPK Phonska } & \multicolumn{2}{c}{ Panjang Tanaman (cm) } \\
\cline { 2 - 3 } & $20 \mathrm{HST}$ & $40 \mathrm{HST}$ \\
\hline $\mathrm{N}_{0}=$ Kontrol & 30.55 & 40.71 \\
$\mathrm{~N}_{1}=250 \mathrm{~g} /$ plot $(400 \mathrm{~kg} / \mathrm{ha})$ & 30.13 & 40.66 \\
$\mathrm{~N}_{2}=500 \mathrm{~g} /$ plot $(800 \mathrm{~kg} / \mathrm{ha})$ & 29.89 & 40.64 \\
\hline $\mathrm{BNT}_{0,05}$ & - & - \\
\hline
\end{tabular}

Menurut Lakitan (2012) tanaman berkembang dengan baik apabila unsur hara yang dibutuhkan cukup tesedia, apabila dosis unsur hara terlalu rendah maka pertumbuhan tanaman akan terganggu, sedangkan apabila unsur hara pada dosis tinggi maka tidak akan meningkatkan hasil bahkan dapat menghambat pertumbuhan tanaman. Tanaman akan tumbuh subur bila nutrisi yang dibutuhkan tanaman tersedia dalam jumlah yang cukup dan dalam bentuk yang sesuai untuk diserap tanaman. Tersedianya unsur hara dalam jumlah yang seimbang untuk pertumbuhan tanaman menyebabkan proses pembelahan, pembesaran dan pemanjangan sel akan berlangsung cepat yang mengakibatkan beberapa organ tanaman tumbuh cepat sehingga mampu membentuk organ-organ pertumbuhan diantaranya titik tumbuh dan digunakan dalam perkembangan batang (Fitrianti dkk., 2018).

\section{Jumlah Buah Per Tanaman (Buah)}

Nilai rata-rata jumlah buah per tanaman semangka akibat pupuk NPK Phonska setelah di sajikan pada Tabel 8. Tabel 8 memperlihatkan bahwa pemberian pupuk NPK menunjukkan pengaruh tidak nyata terhadap jumlah buah per tanaman semangka. Hal ini di sebabkan oleh faktor iklim, di mana pada saat tanaman memasuki fase pembungaan terjadi perubahan iklim yaitu dari musim panas saat tanam kemudian musim hujan saat pembungaan, sehingga mengakibatkan proses pembuahan menjadi lambat dan menghasil jumlah buah dalam keadaan rendah, karena disebabkan oleh banyak bunga yang rontok dan layu.

Tabel 8 Rata-rata Jumlah Buah Per Tanaman Semangka Akibat Pemberian Pupuk NPK Phonska

$$
\text { Perlakuan Pupuk NPK Phonska Jumlah Buah Per Tanaman (Buah) }
$$

\begin{tabular}{cc}
\hline $\mathrm{N}_{0}=$ Kontrol & 1.65 \\
$\mathrm{~N}_{1}=250 \mathrm{~g} / \mathrm{plot}(400 \mathrm{~kg} / \mathrm{ha})$ & 1.64 \\
$\mathrm{~N}_{2}=500 \mathrm{~g} /$ plot $(800 \mathrm{~kg} / \mathrm{ha})$ & 1.63 \\
\hline BNT $_{0,05}$ & - \\
\hline
\end{tabular}

Hal ini dikarenakan oleh kondisi bunga yang basah, sehingga menyebabkan benang sari lengket satu sama lain karena terikat oleh air, sehingga tidak bisa bertemu dan membuahi kepala putik.Wahyudi (2014), menyatakan bahwa selain karena faktor genetis, faktor lingkungan merupakan faktor penting yang dapat meningkatkan atau menghambat pertumbuhan dan perkembangan tanaman, dengan kata lain dapat dikatakan bahwa faktor lingkungan merupakan faktor penentu keberhasilan usaha budidaya tanaman. Menurut Darjanto dan Satifah (2014) pembentukan bunga adalah peralihan dari fase vegetatif ke fase generatif. Peralihan fase ini ditentukan oleh faktor genetik dan sebagian lagi ditentukan oleh faktor lingkungan seperti unsur hara dan iklim. 


\section{Berat Buah Per Tanaman (kg)}

Nilai rata-rata berat buah per tanaman semangka akibat pupuk NPK Phonska setelah diuji BNT 0,05 di sajikan pada Tabel 9. Tabel 9 memperlihatkan bahwa pemberian pupuk NPK menunjukkan pengaruh tidak nyata terhadap berat buah per tanaman semangka, walaupun berdasarkan hasil perhitungan analisis sidik ragam tidak berpengaruh nyata, akan tetapi dari semua perlakuan tersebut pemberian pupuk NPK dosis $400 \mathrm{~kg} / \mathrm{ha}\left(\mathrm{N}_{1}\right)$ menberikan hasil berat buah per tanaman terbaik bila dibandingkan dengan perlakuan lain. Hal ini dikarenakan unsur hara yang terkandung dalam pupuk NPK yang mampu menyediakan nutrisi bagi proses metabolisme tanaman sehingga semakin dengan dosis yang diberikan mampu meningkatkan berat buah tanaman semangka, walaupun tidak menunjukkan pengaruh nyata. Hal ini juga disebabkan oleh oleh jumlah buah per tanaman yang tidak banyak yaitu hanya 1 buah per tanaman, sehingga unsur hara yang diberikan melalui pupuk tersebut terpusat untuk satu buah, sehingga bobot dan kualitas buah yang terbentuk lebih baik.

Tabel 9. Rata-rata Berat Buah Per Tanaman Semangka Akibat Pemberian Pupuk NPK Phonska

\begin{tabular}{cc}
\hline Perlakuan Pupuk NPK Phonska & Berat Buah Per Tanaman $(\mathrm{kg})$ \\
\hline $\mathrm{N}_{0}=$ Kontrol & 2.08 \\
$\mathrm{~N}_{1}=250 \mathrm{~g} /$ plot $(400 \mathrm{~kg} / \mathrm{ha})$ & 2.35 \\
$\mathrm{~N}_{2}=500 \mathrm{~g} / \mathrm{plot}(800 \mathrm{~kg} / \mathrm{ha})$ & 2.33 \\
\hline $\mathrm{BNT}_{0,05}$ & - \\
\hline
\end{tabular}

Muliadi dan Kartasapoetra (2014) menyatakan bahwa pupuk NPK mengandung unsur hara makro yang lengkap yang dapat membantu dalam menyediakan unsur hara untuk pertumbuhan dan perkembangan tanaman semangka. Selanjutnya dengan makin baik kuwalitas buah yang dihasilkan, maka makin diikuti dengan meningkatnya produksi buah yang dihasilkan. Mulyani Sutedjo (2013), bahwa untuk pertubuhan vegetatif dan generatif tanaman diperlukan unsur-unsur hara terutama $\mathrm{N}, \mathrm{P}$ dan K. Unsur $\mathrm{N}$ diperlukan untuk pembentukan karbohidrat, protein, lemak dan persenyawaan organik lainnya. Unsur P berperan dalam pembentukan bagian generatif tanaman. Soemarno (2011), menyatakan bahwa unsur Kalium meningkatkan aktivitas fotosintesis dan mempunyai pengaruh yang lebih besar terhadap proses pembentukan buah dari pada pertumbuhan batang dan daun.

\section{Berat Buah Per Plot (kg)}

Nilai rata-rata berat buah per plot tanaman semangka akibat pupuk NPK Phonska setelah diuji BNT $_{0,05}$ di sajikan pada Tabel 10.

Tabel 10. Rata-rata Berat Buah Per Plot Tanaman Semangka Akibat Pemberian Pupuk NPK Phonska

\begin{tabular}{cc}
\hline Perlakuan Pupuk NPK Phonska & Berat Buah Per Plot $(\mathrm{kg})$ \\
\hline $\mathrm{N}_{0}=$ Kontrol & $26.97^{\mathrm{a}}$ \\
$\mathrm{N}_{1}=250 \mathrm{~g} /$ plot $(400 \mathrm{~kg} / \mathrm{ha})$ & $31.49^{\mathrm{b}}$ \\
$\mathrm{N}_{2}=500 \mathrm{~g} / \mathrm{plot}_{(800 \mathrm{~kg} / \mathrm{ha})}$ & $27.08^{\mathrm{a}}$ \\
\hline BNT $_{0,05}$ & 2.90
\end{tabular}

Keterangan : Angka yang diikuti oleh huruf yang sama pada kolom yang sama berbeda tidak nyata pada Uji $\mathrm{BNT}_{0.05}$

Tabel 10 memperlihatkan bahwa pemberian pupuk NPK menunjukkan pengaruh sangat nyata terhadap berat buah per plot tanaman semangka. Berat buah perplot tanaman semangka tertinggi dijumpai pada perlakuan pemberian pupuk NPK dosis $250 \mathrm{~g} /$ plot $\left(\mathrm{N}_{1}\right)$, sedangkan berat buah per plot tanaman semangka terendah dijumpai pada perlakuan tanpa pemberian pupuk NPK $\left(\mathrm{N}_{0}\right)$. Hasil tersebut menunjukkan bahwa dosis pupuk NPK $250 \mathrm{~g} /$ plot yang diberikan dapat meningkatkan kualitas dan kuantitas dari buah semangka. Hal ini disebabkan unsur P dan K yang terkandung di 
dalam pupuk NPK dapat membantu proses pembentukan buah yang maksimal sehingga berat buah per plot yang dihasilkan akan meningkat.

Unsur hara P sangat mempengaruhi pembentukan buah tanaman semangka. selain itu unsur P juga dapat memperbesar pembentukan buah, selain itu ketersediaan P sebagai pembentuk ATP akan menjamin ketersediaan energi bagi pertumbuhan sehingga pembentukan asimilat dan pengangkutan ketempat penyimpanan dapat berjalan dengan baik. Kalium berperan penting dalam proses fisiologis, metabolisme karbohidrat, pembentukan, pemecahan dan translokasi pati. Kadar kalium yang cukup pada tanaman mengakibatkan normalnya pembentukan dan pembesaran ukuran buah pada bagian tanaman. Menurut Fitrianti dkk. (2018) menyatakan bahwa terjadinya respon yang nyata pada hasil karena meningkatnya laju proses fotosintesis dimana unsur kalium berperan dalam fotofosforilasi dalam proses fotosintesis. Tanaman yang mendapatkan $\mathrm{K}$ cukup akan tumbuh lebih cepat karena $\mathrm{K}$ dapat memelihara tekanan turgor sel secara konstan. Hasil penelitian Muhadan (2016) menunjukkan pemberian pupuk NPK $250 \mathrm{~kg} / \mathrm{ha}$ berpengaruh nyata dalam meningkatkan pertumbuhan dan hasil tanaman semangka yaitu panjang tanaman, jumlah daun, diameter buah dan berat buah per tanaman semangka.

\section{Pengaruh Interaksi}

Hasil uji F pada analisis sidik ragam menunjukkan bahwa tidak terdapat interaksi yang nyata antara perlakuan abu sabut kelapa dan pupuk NPK terhadap semua parameter yang diteliti antaranya pertumbuhan panjang tanaman, jumlah buah per tanaman, berat buah per tanaman, berat buah per plot. Hal ini disebabkan oleh tanaman semangka yang tidak mampu merespon dengan baik terhadap pemberian abu sabut kelapa dan pupuk NPK, sehingga dengan pemberian kombinasi taraf tertinggipun pertumbuhan dan hasil tanaman semangka yang diperoleh tetap tidak berbeda nyata.

\section{KESIMPULAN}

1. Pemberian abu sabut kelapa berpengaruh sangat nyata terhadap berat buah semangka per plot, akan tetapi berpengaruh tidak nyata terhadap pertumbuhan tinggi tanaman, jumlah buah, dan berat buah per tanaman tanaman semangka. Perlakuan terbaik dijumpai pada perlakuan abu sabut kelapa dosis $2500 \mathrm{~g} / \mathrm{plot}$ atau 4 ton/ha $\left(\mathrm{A}_{1}\right)$.

2. Pemberian pupuk NPK berpengaruh sangat nyata terhadap berat buah semangka per plot, akan tetapi berpengaruh tidak nyata terhadap pertumbuhan tinggi tanaman, jumlah buah, dan berat buah per tanaman, tanaman semangka. Perlakuan terbaik dijumpai pada perlakuan pupuk NPK dosis $250 \mathrm{~g} / \mathrm{plot}$ atau $400 \mathrm{~kg} / \mathrm{ha}\left(\mathrm{N}_{1}\right)$.

3. Tidak terdapat interaksi yang nyata antara kombinasi perlakuan abu sabut kelapa dan pupuk NPK terhadap semua peubah yang diamati.

\section{DAFTAR PUSTAKA}

Amilda, P. dan Putri, E. 2019. Respon Tanaman Kedelai (GLYCINE MAX (L.) MERR) Terhadap Penggunaan Pupuk Organik. Majalah Ilmiah Universitas Almuslim, Vol. 11 No. 3 hal. 21-26

Arinong, A. Rahman, H. Rukka, dan L. Vibriana. 2008. Pertumbuhan dan Produksi Tanaman Sawi dengan Pemberian Bokashi. J-Agrisistem vol. 4 no. 2 hal. 25-28.

Darjanto, Satifah, S. 2014. Pengetahuan Dasar Biologi Bunga dan Teknik Penyerbukan Silang Buatan. Jakarta : PT Gramedia. 
Daud R., Bahua M. I. dan Rahim Y. 2017. Pertumbuhan Dan Produksi Tanaman Semangka (Citrullus vulgaris Schard) Melalui Pemberian Pupuk Organik Cair Dan Abu Sabut Kelapa. Skripsi Program Studi Agroteknologi Fakultas Pertanian Universitas Negeri Gorontalo.

Fitrianti , Masdar dan Astiani. 2018. Respon Pertumbuhan dan Produksi Tanaman Terung (Solanum melongena) Pada Berbagai Jenis Tanah dan Penambahan Pupuk NPK Phonska. Agrovital. Jurnal Ilmu Pertanian Universitas Al Asyariah. Vol. 3 No. 2 hal. 60-64

Foth, H. D. 2014. Petunjuk Penggunaan Pupuk. Penebar Swadaya. Jakarta.

Hakim, N., Nyakpa, M.Y., Lubis, A.M., Nugroho, S.G., Saul, M.R., Diha, M.A., Go Ban Hong, Bailey, H.H. 2012. Dasar Dasar Ilmu Tanah. Penerbit Universitas Lampung. Lampung.

Hutasoit, M. G. P., Yetti, H. dan Silvina, F. 2018. Pengaruh Pupuk Kascing Dan Npk Terhadap Pertumbuhan Dan Produksi Tanaman Semangka (Citrullus lanatus Schard). Jurnal Agroteknologi Universitas Riau. Vol. 5 No. 2 hal 12.

Syah, M., Yetti, H., dan Yoseva, S. 2016. Pengaruh Pemberian Bokashi Dan NPK Terhadap Pertumbuhan Dan Produksi Tanaman Semangka (Citrullus vulgaris Schard). Agrotechnolog. Department. Agriculture Faculty. University of Riau. Jom Faperta. Vol 3 No. 2

Novizan, 2012. Petunjuk Pemupukan yang Efektif. PT. Agromedia Pustaka. Jakarta.

Prajnanta, F. 2011. Kiat Sukses Bertanam Semangka Berbiji. Penebar Swadaya, Jakarta

Prawitasari, T. 2013. Siknal Fisiologi Pada Transisi ke Pertumbuhan Perkembangan Reproduktif. P2KSDM, Bogor.

Sutedjo, M. M. 2012. Pupuk dan Cara Pemupukan. Jakarta: PT. Rieneka Cipta

Suwandi dan Sulistyono, A., 2015. Kajian Dosis Pupuk Phonska Pada Dua Varietas Semangka Terhadap Pertumbuhan dan Hasil Buah Semangka. AgritropJurnalIlmu-IlmuPertanian. hal 5457.

Hermawati. T. 2015. Respon Tanaman Semangka (Citrullus vulgaris hard.) Terhadap Pemberian Berbagai Dosis Abu Sabut Kelapa. Jurnal Agronomi. Vol. 11 No. 2. hal 77-80

Trisnaningsih, U., Harijanto S dan Bambang. 2014. Pengaruh Takaran Abu Sabut Kelapa Terhadap Pertumbuhan Dan Hasil Tanaman Semangka (Citrullus vulgaris Schard.) Kultivar Mahesa. Jurnal Agroswagati. Vol 2. No 2. hal 12

Wahyudi, A. 2014. Peningkatan Produksi Buah Semangka Menggunakan Inovasi Teknologi Budidaya Sistem "ToPAS". Inovasi dan Pembangunan - Jurnal Kelitbangan Vol. 02 No. 02 hal. 94-95 